Bull.Fac, Agric.,Cairo Univ.,63:8-18 (2012).

\title{
PHYSICAL AND MECHANICAL PROPERTIES OF TOMATO PLANT TO DESIGNA HARVEST MACHINE
}

(Received: 23. 1. 2012)

\author{
By \\ M. M. Atallah \\ Agricultural Engineering Research Institute, Agriculture Research Center, Giza, Egypt.
}

\begin{abstract}
This study was carried out during the summer seasons from 2008 to 2009 at Kaha Horticultural Research Station, Kalubia Governorate the investigat physical and mechanical properties of tomato crop. The characteristics used were length, width, weight, volume, surface area, density rigidity force, angle of repose and angle of friction of three different varieties of tomato (Florada, Super B and Castle Royal) and three hybrids (Bregenith, Fanfare and Heinz).

The obtained results can be applied to design and develop of tomato harvester functional units summarized in the following points: Plant characteristics for cultivars and hybrids: Angle of inclination of the main branches on the vertical plane was averaged $25^{\circ}$, the highest percentage of the fruits $(95 \%)$ was found in circumference the inter plant.

Physical properties of tomato fruit: Heights for cultivars were averaged $62.23,55.92,54.12 \mathrm{~mm}$, respectively, for hybrids averaged $63.07,52.69,53.14 \mathrm{~mm}$, respectively. Width for cultivars were averaged 58.26, 47.53 and $49.62 \mathrm{~mm}$, respectively, and for hybrids were averaged 58.19, 62.72 and 61.44 $\mathrm{mm}$, respectively. Sphericity for cultivars averaged (1.06, 1.18 and 1.09), respectively and the fruit sphericity for hybrids were $(1.09,1.17$ and 0.78$)$, respectively. Mass for cultivars were averaged (131, 87.5 and $76 \mathrm{~g}$ ), respectively, and for hybrids averaged (128.5, 106.5 and $123.5 \mathrm{~g}$ ), respectively. Volume for cultivars averaged $\left(129,85\right.$ and $\left.69.5 \mathrm{~cm}^{3}\right)$, respectively, and for hybrids averaged $(126.5,105.5$ and $121.75 \mathrm{~cm}^{3}$ ), respectively. The deformation range increased from $0.85-2.6$ to $6.5-7.9 \mathrm{~mm}$ by increasing loading from 1 to $6 \mathrm{~N}$. Meanwhile, the deformation range increased from $0.85-6.5$ to $2.6-7.9$ by increasing loading time from 20 to $60 \mathrm{~s}$. The maximum impact heights, which caused damage was $1.0 \mathrm{~m}$.

While, the corresponding impact height which caused bruise was $0.75 \mathrm{~m}$.

The present work aimed at studying the harvest machine design using the physical and mechanical properties of tomato plant.
\end{abstract}

Key words: cultivars, hybrids, physical and mechanical properties, tomato.

\section{INTRODUCTION}

Tomato is one of the most important vegetable crops in Egypt for fresh consumption and processing.

The objectives of this study were to investigate the physical and mechanical properties of tomato plant. This knowledge is useful in selecting machine-harvest, for establishing design and developing specifications for fruit tomatoharvesting machines .

The physical property determinations are useful to build up data base for standardizing each crop that will be required for the international marketing (El-Raie et al., 1996). Hojat et al. (2008) studied some physical and mechanical properties such as dimensions, geometric mean diameter, sphericity, surface area, bulk density, real density, porosity, volume, mass, 1000- unit mass, coefficient of static friction on various surface and rupture force in 3 axes of apricot fruits. Abd-Allah (1995) found highly significant differences for plant height among the tested genotypes of tomato; Marmande was the tallest plant while Peto 86 was the shortest one.

Mouhamed and Hewedy (1994) found that plant height of determinate tomato cultivars differed from $29 \mathrm{~cm}$ to more than $85 \mathrm{~cm}$. However.Hanna et al. (1993) stated that, the angle of the repose is very important in the determination of the inclination angle of the machine hopper tank.

Bishop and Maunder (1990) stated that there are four basic causes of damage: pressure, impact, cutting, and friction. Damage by pressure is not 
typical on a grading line. Cutting should also not be a problem, as if cut wounds are found it is normally a relatively easy task to protect shape edges. Impact and friction are the two most important causes of damage.

Balls (1986) reported that there is an inherent damage capability in hand-harvesting system, as well as in mechanical harvesting; however, the latter is often more severe and likely to have less chance of being observed and corrected. Damage exists in two forms; external, caused by cutting, gouging or abrasion; while internal bruising caused by pressure or impact forces. The former is more easily detected, but more obvious in fresh market produce. Bruising often has a delayed visual effect, and consequently cannot be detected and rectified at source bruising might be enhanced by certain conditions.

Peterson and colario (1990) found that fruitfruit impacts were a major cause of damage in the mechanical harvesting of peaches, and established bruising levels for a $400 \mathrm{~mm}$ drop onto other fruit as $11 \%$ bruised for Red Globe, $3 \%$ bruised for Loring. 3\% bruised for Red Skin and 0\% bruised for Bounty; and for a $800 \mathrm{~mm}$ drop, $64 \%$ bruised for Red Skin.

Haydar et al. (2007) mentioned that properties are necessary for the design of equipments for harvesting, processing, and transportation, separating and packing. Technological properties are length and diameter of fruits, mass, volume of fruits, geometric mean-diameter, sphericity, bulk density, fruits density, porosity, projected area, static and dynamic coefficient of friction.

Huang et al. (2000) stated that the basic physical properties (shapes, sizes and mass, slanting and rolling angles, coefficients of friction and size attribution ratio) of the grading machine used to sort Ziziphus mauritiana were investigated and indexes of physical properties were established to provide information for the design and development of a grading machine suitable for postharvest processes such as cleaning, grading, packing, and preservation.

\section{MATERIAL AND METHODS}

This work was carried out to determine some physical and mechanical properties of six tomato varieties commonly cultivated in Egypt. These varieties are: Cultivars (Florada, Super Strain B and Castle Royal) and Hybrids (Bregenith, Fanfare and Heinz). The physical and mechanical studies may help in choosing, altering or design of a suitable machine for harvesting tomato.

\subsection{Characteristics of tomato plant}

The dimension characteristics of the tomato plant are important in estimating the amount of tomato yield, its plant.

The positions of plant parts above the soil surface were studied and measured on the selected tomato plants. The angle of inclination of each main branch with respect to the vertical plane axis was measured with a protractor with accuracy of 5. Fig. (1) shows the divisions of a tomato plant determination of plant size. It was counted for each plant and the average was calculated.
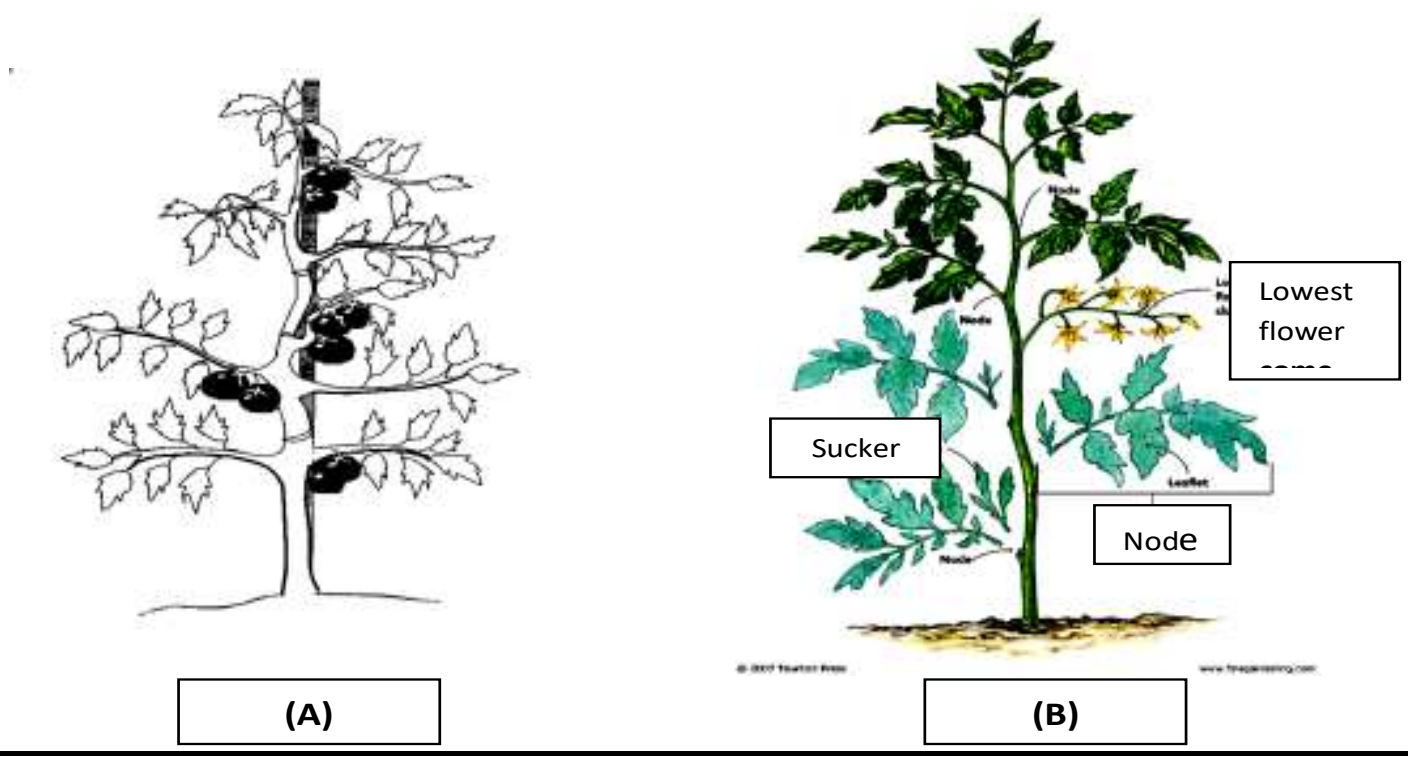

Fig.( 1 ): Division of a tomato plant.

A: The distribution of the tomato fruits on the plant

B: The positions of parts above the soil. 


\subsection{Physical and mechanical properties of} tomato fruits

\subsubsection{Physical properties of tomato fruits}

In order to determine the mean weight and the dimensions of tomato fruits, a sample of 100 fruits was selected randomly for both groups Each fruit of the average sample was weighed using an electric balance with an accuracy of $0.01 \mathrm{~g}$ and using a caliper.

\subsubsection{Mechanical properties of tomato fruits}

2.2.2.1. Static compression force of tomato fruit

The fruit strength is defined by the pericarp hardness, by the magnitude of the static crushing force and by crushing of fruit due to impact (Buyanov and Voronyuk, 1985). The fruits were crushed in two directions, along a major axis $\left(D_{2}\right)$ and a minor axis $\left(D_{1}\right)$ in (Fig., 2). The fruit was put on the flat plastic surface along the axis.

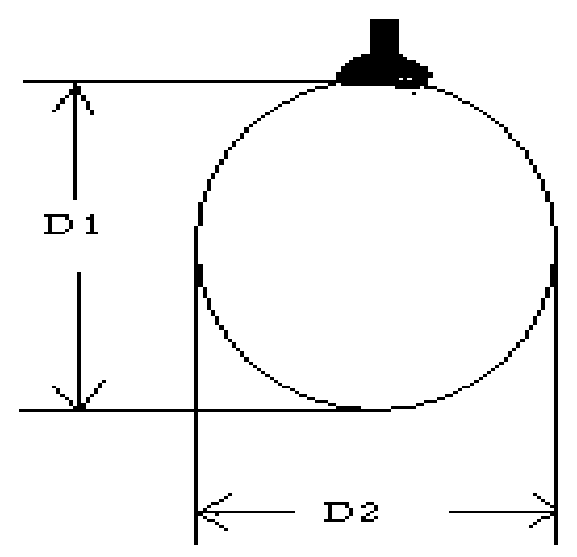

Fig. (2): Tomato fruit dimensions D1 and D2

The weight was put on the fruit and increased gradually to the maximum point at which cracks begin to appear then compression stopped. Before the test, the fruit dimensions and their weights were recorded. After removing the loads the dimensions D1 and D2 were measured again and the fruit deformation was calculated as follows:

Deformation along $D_{1}$ axis $=D_{11}-D_{12} \ldots \ldots \ldots \ldots$

Where: $D_{11}=$ the dimension before the test $D_{12}=$ the dimension after the test

Deformation along $D_{2}$ axis $=D_{22}-D_{21} \ldots \ldots \ldots$...

Where: $D_{22}=$ the dimension before the test $D_{21}=$ the dimension after the test

\subsubsection{Detachment force of tomato fruit $(F)$}

Tomato fruits are attached to their supporting twig through a small button (calyx). Tomato fruit detachment force is an indicator for the degree of fruit maturity (Ghonim, 1986) and the magnitude of twig torsion shear stress. Tomato fruit detachment force was measured to estimate the variation of fruit detachment force. The detachment force was measured for the tomato fruits exist by using the detachment force meter (Fig. 3). After tomato fruit separation from the twig, fruit dimensions; D1, D2 and twig diameter were measured with a caliper and then the fruit was weighed. During the harvesting time, the ripe cohort of fruit, calyx and twig is attached to the branches of the tree, to attenuate that attachment at any location (1) or (2) or (3) of (Fig. 4) the fruit will be separated with its own twig.

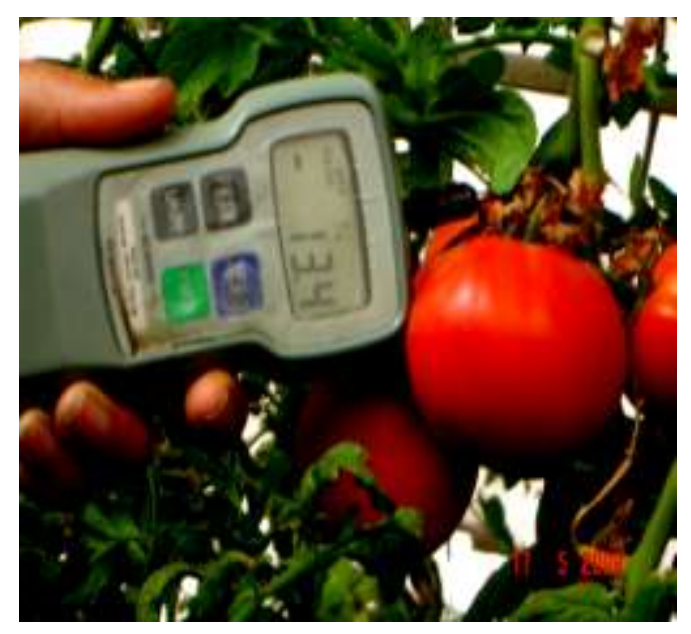

Fig. (3): The detachment force meter.

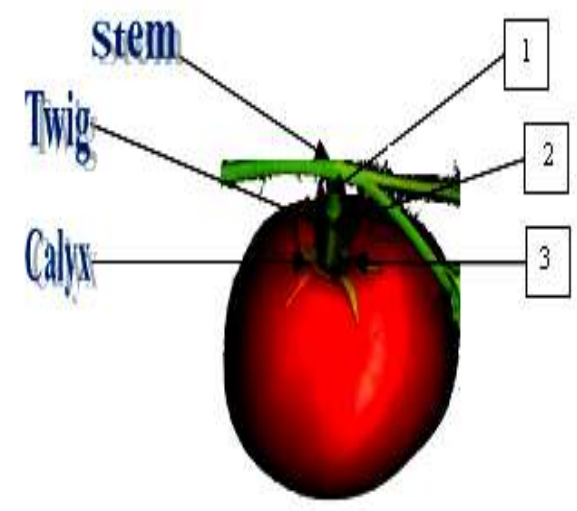

Fig. (4): Major diameters of a tomato fruit

\subsection{Design-idea of the tomato harvester the pull-type}

A design-idea of the tomato harvester the pulltype in (Fig. 5) allows the growers who purchase the machines a great degree of adaptability for harvesting in different environments. 


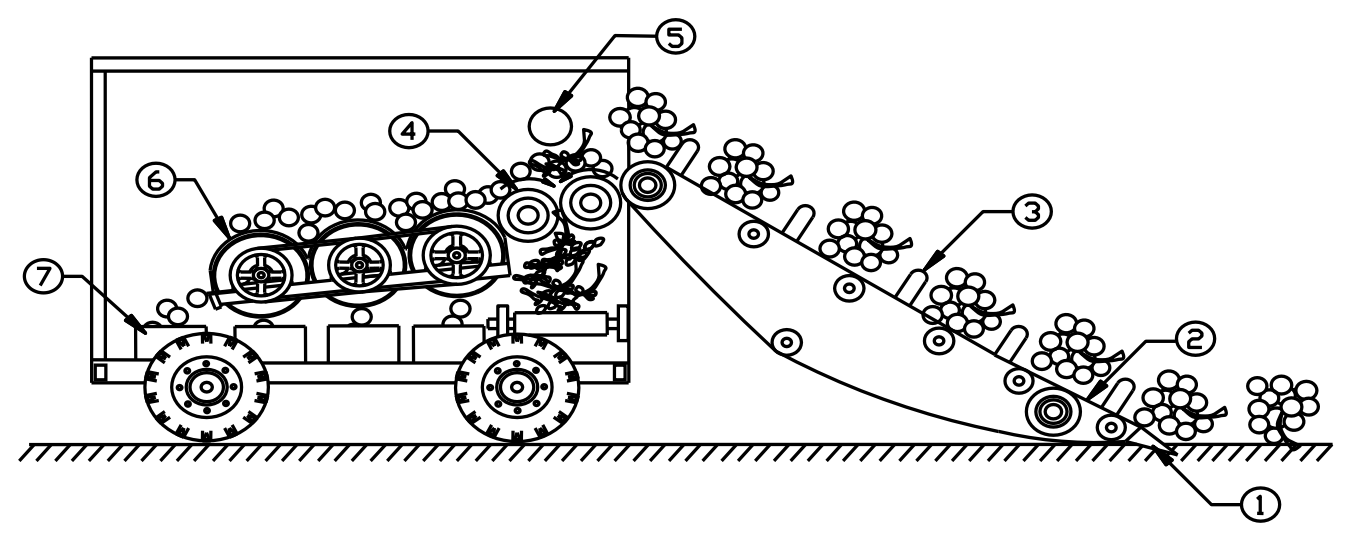

Fig. (5): Schematic design-idea of the tomato harvester the pull-type.

1- Width cutting bar more than the spacing between the rows of plants and positioned perpendicular to the plant row, as the tractor moves forward. Tomato plants are thus uprooted from below the ground surface to harvesting.

2-Conveyor belt for plant matter and shaker are for fruit cleaning from vine mass and debris the vines, leaves slide back down the concave.

3- Rigid fingers are arranged on the parallel rods of the elevator for lifting plants and prevent movement of loose fruit. The leading end of the elevator is raised or lowered hydraulically by the tractor operator. Speed of the elevator is adjusted to conform to the forward speed of the tractor.

4- Fruit-laden plants are carried up the $45^{\circ}$ incline to a height of about $160 \mathrm{~cm}$ from bed surface, and are discharged to two cylinders for detaching the fruits from The plant stems, leaves and vine are severed. The cylinders was tending to dislodge the fruit for grading

5- Two workers standing on opposite sides of two cylinders inclined $30^{\circ}$ for trash removal and green fruits, (the number depending primarily upon the harvest rate and the maturity and condition of the fruit.).

6- The grading machine is conveyed directly behind the harvester for grading fruits into shallow boxes to reduce pressure bruising on the trailer.

7- Medium and smallest fruit anticipated diameter of fruit to be harvested into boxes, while the largest fruit plants are discharged at the rear of the machine.

\section{RESULTS AND DISCUSSION \\ 3.1. Plant characteristics}

The characteristics of tomato plant as the dimensions of main branches and inclination angle of the main branches on the vertical plane were measured for six different varieties and hybrids of tomato.

\subsubsection{Dimensions of tomato plant components}

The dimension characteristics of the tomato plant and distribution percentage on the plant are important in determining harvesting methods. Table (1) shows the average dimensions of a tomato plant components and Table (2) shows plant height and No. of branches in the two seasons (2008 \& 2009). The main branches in the two seasons for the cultivars averaged $(9.01,8.87$, $12.2 \mathrm{~cm})$, and for the hybrids were $(13.9,17.1$, $16.1 \mathrm{~cm}$ ), respectively.

\subsubsection{Fruit distribution cluster on the plant}

Fruits spatial position (fruits distribution) and percentage are illustrated in Fig. (1-A). The results showed that, the highest percentage of the fruits $(95 \%)$ was found in circumference the inter plant. 3.2. Physical and mechanical properties of tomato fruits

The physical and mechanical properties of the tested tomato fruits were evaluated. The obtained results are used to design-idea of the tomato harvester the pull-type .

\subsubsection{Physical properties of tomato fruits}

Tables 3 and 4 show the dimensions, sphericity, mass, volume and real density. These parameters were measured on 100 fruit sample for each variety, according to the standards set in (Mohsenin,1986) (Fig. 6 and 7).

\subsubsection{Dimensions of fruit}

Tables 3 and 4 and Fig. (6) indicate that the fruit height ranges for the cultivars (52.72 -71.73, $53.97-57.87,50.97-57.26 \mathrm{~mm}$ ) and (average $62.23,55.92,54.12 \mathrm{~mm}$ ), respectively. The fruit height ranges of the sample for the hybrids were $(56.7-69.44,48.83-56.55,49.83-56.44 \mathrm{~mm})$ 
Table (1): Average dimensions of the tomato plant components for six tomato cultivars and hybrids.

\begin{tabular}{|l|l|l|l|l|l|l|l|l|l|}
\hline \multirow{2}{*}{$\begin{array}{l}\text { Plant } \\
\text { height, } \\
\text { cm }\end{array}$} & \multicolumn{5}{|c|}{ Main branches } & \multicolumn{2}{|c|}{$\begin{array}{c}\text { Angle of inclination } \\
\text { of the main branches } \\
\text { on the vertical plane, }\end{array}$} \\
\cline { 2 - 11 } & \multicolumn{3}{|c|}{ Length } & \multicolumn{3}{|c|}{ Diameter } & \multicolumn{3}{c|}{ degree } \\
\cline { 2 - 10 } & \multicolumn{3}{|c|}{ cm } & \multicolumn{3}{|c|}{ mm } & Max & Min. & Mean \\
\cline { 2 - 10 } & Max & Min. & Mean & Max & Min. & Mean & Max \\
\hline 170 & 50 & 35 & 42.5 & 10 & 6 & 8 & 35 & 15 & 25 \\
\hline
\end{tabular}

Table (2): Average performance of the six tomato cultivars and hybrids for plant height and no. of branches in the two seasons $(2008 \& 2009)$.

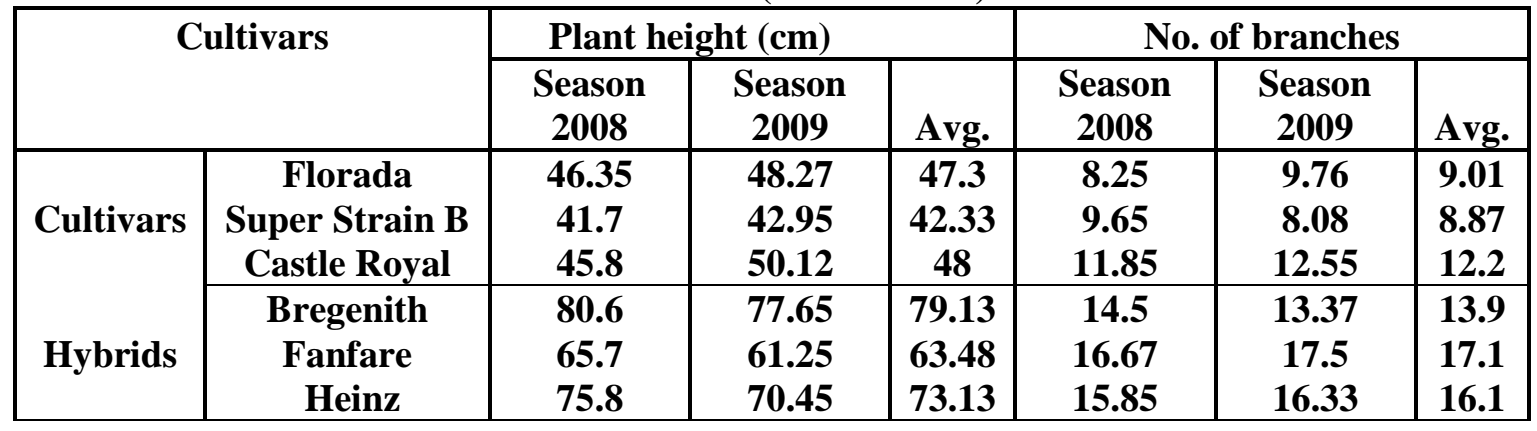
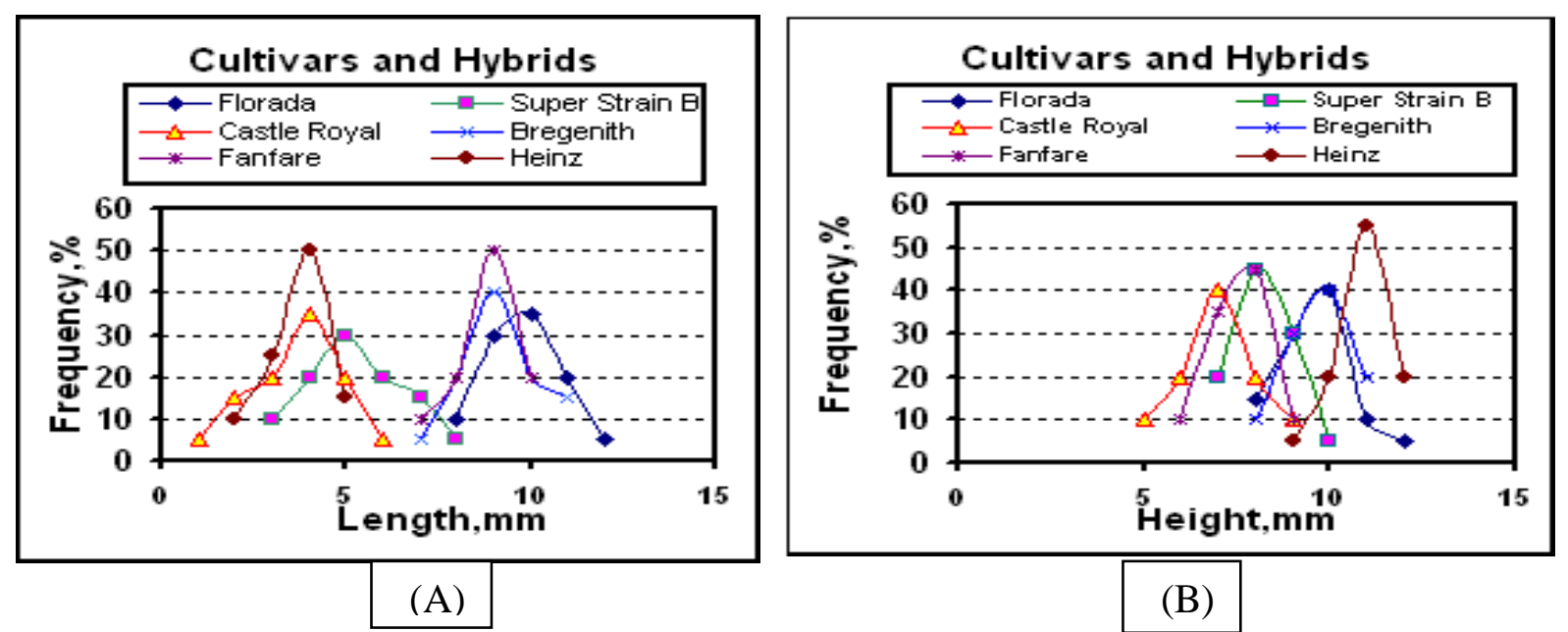

(B)

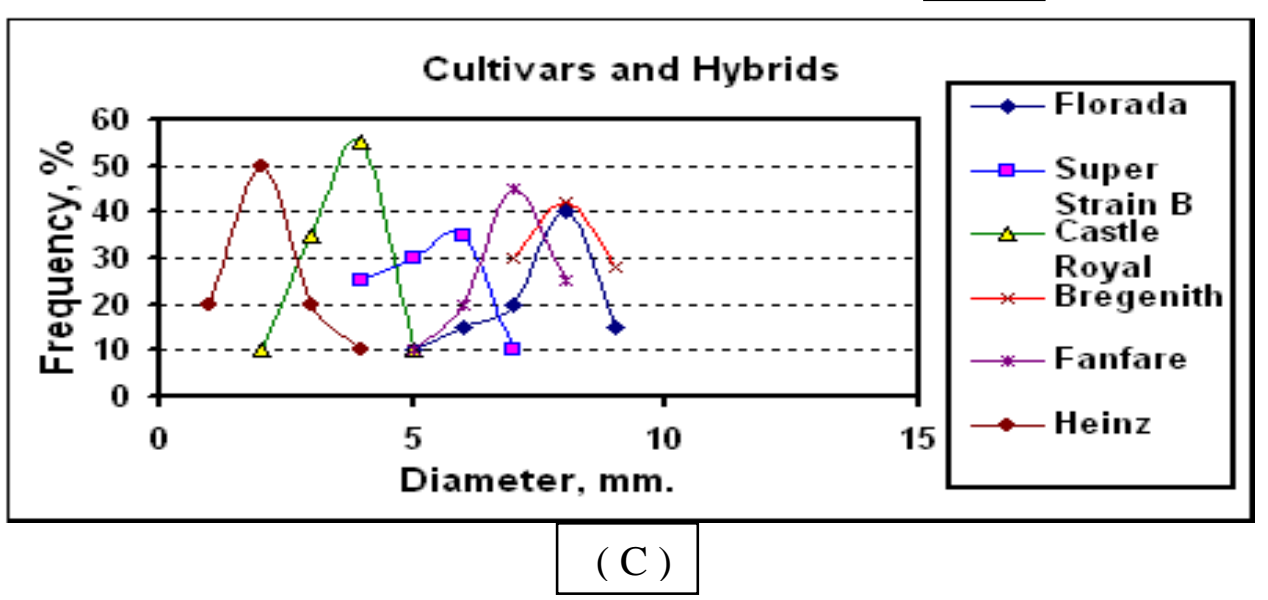

Fig. ( 6 ): Frequency distribution of fruit dimensions of tomato fruits, A,B,C. 
and (average 53.07, 52.69, $53.14 \mathrm{~mm}$ ), respectively. The most frequent percentages more than $90 \%$ of tomato fruits in the sample for the cultivars were $(55-60,60-65,65-70) \mathrm{mm}$ height and for the hybrids $(55-60,60-65,65-70) \mathrm{mm}$ height.

The fruit width for the cultivars were $(53.75$ $62.77,46.24-48.82$ and $49.34-49.90 \mathrm{~mm}$ ) and (average 58.26, 47.53 and $49.62 \mathrm{~mm}$ ), respectively. The fruit width ranges of the sample for the hybrids were $(54.2-62.17,57.68-67.75$ and $57.68-65.20 \mathrm{~mm}$ ) and (average 58.19, 62.72 and $61.44 \mathrm{~mm}$ ), respectively. The most frequent percentages more than $90 \%$ of tomato fruits in the sample for cultivars were $(55-60,60-65,65-70)$ $\mathrm{mm}$ width and for the hybrids $(55-60,60-65,65-$ 70) mm width .

\subsubsection{Shape and size of the fruit}

The fruit mass and volume affect the required amount of kinetic energy of the fruit during harvesting operation .

If sphericity is less than 0.9 , the fruit belongs to oblate group; if sphericity is greater than 1.1 , it belongs to the oblong group. The remaining fruits with intermediate index values are considered to be round (Buyanov and Voronyuk, 1985).

Tables 3 and 4 and Fig. 7 indicate that the fruit sphericity ranged in the sample for the cultivars were ( $0.87,1.08$ and 1.05$)$, respectively and the fruit sphericity ranges in the sample for the hybrids were (1.41, 1.26 and 1.45), respectively. The most frequent percentage $(85.8 \%)$ of tomato fruits in the sample was round (sphericity 0.9 $1.2)$ and $(14.2 \%)$ of tomato fruits in the sample were oblong (sphericity $1.2-1.4$ ).

\subsubsection{Mass and volume of fruit}

Tables 3 and 4 indicate that the fruit mass ranges of the sample for the cultivars were (102$160,76-99$ and 66-86 g) with an average (131, 78.5 and $76 \mathrm{~g}$ ), respectively. The fruit mass ranges for the hybrids were (99- 158, 98-115 and 108$139 \mathrm{~g}$ ) with an average (128.5, 106.5 and $123.5 \mathrm{~g}$ ), respectively. The most frequent percentage (93.15 $\%$ ) of tomato fruits in the sample was $90-75 \mathrm{~g}$ mass.

The fruit volume ranges of the sample for the cultivars were $\left(101-152,70-100\right.$ and $\left.60-79 \mathrm{~cm}^{3}\right)$ with an average $\left(126.5,85\right.$ and $\left.69.5 \mathrm{~cm}^{3}\right)$, respectively. The fruit volume ranges of the sample for the hybrids were $(102.5-150.5,101$ 112 and 106-137.5 $\left.\mathrm{cm}^{3}\right)$ with average of (126.5, 106.5 and $121.75 \mathrm{~cm}^{3}$ ), respectively. The most frequent percentage $(90.45 \%)$ of tomato fruits in the sample was $95-70 \mathrm{~cm}^{3}$. Fig. 7 indicates presents the best fitted curves of the relations between fruit volume and mass.

\subsubsection{Real density of the fruit}

The fruit real density ranges of the sample for the cultivars were $(0.85,0.87,0.83-0.97,0.93$, $\left.0.91 \mathrm{~g} / \mathrm{cm}^{3}\right)$ with an average $(0.91,0.90,0.86)$, respectively. The fruit real density ranges of the sample for the hybrids were $(0.92,0.88,0.89-$ $\left.0.99,0.95,0.93 \mathrm{~g} / \mathrm{cm}^{3}\right)$ with an average $(0.96$, $0.92,0.91)$, respectively. The most frequent percentage $(76.2 \%)$ of tomato fruits in the sample was $0.95-0.98 \mathrm{~g} / \mathrm{cm}^{3}$ real density.

\subsubsection{Mechanical properties of tomato fruits}

\subsubsection{Fruit detachment force}

The detachment force depends on the twig diameter. The relationship between detachment force and twig diameter is plotted in Fig. 8. It can be seen that the detachment force increased as the twig diameter increased.

\subsubsection{Friction, rolling and repose angles of tomato fruits}

Friction, rolling and repose angle play an important role in the design most be found such that the relative value of frictional resistance is as low as possible.

The suitable surface, which gives a low value of friction coefficient between the machine surfaces and tomato fruit surface, must be found to satisfy the design requirements. Table 5 shows friction and rolling angles of tomato fruits. The maximum friction angle 11-19 degree and rolling angle ranges 17 - 40 degree were obtained with wood surface. Whereas, the minimum ranges of friction and rolling angles 7 - 15 degrees and 12 - 19 degrees respectively, were obtained with aluminum surface.

\subsubsection{Deformation of fruits}

Fig. 9 shows the average deformation of tomato fruits at different loading weights and times. The deformation range increased from $0.85-2.6$ to $6.5-7.9 \mathrm{~mm}$ by increasing loading from 1 to $6 \mathrm{~N}$.

Meanwhile, the deformation range increased from $0.85-6.5$ to $2.6-7.9 \mathrm{~mm}$ by increasing loading time from 20 to $60 \mathrm{~s}$.

\subsubsection{Impact height}

Impact height must be studied as one of the important factors for determining the height, which causes the fruit damage and the corresponding potential energy of fruit to avoid damage. The obtained results from the present study from impacting the tomato fruits was plotted in Fig. 10. The maximum impact heights, which caused damage for tomato fruit, are $1.0 \mathrm{~m}$. While, the corresponded impact height which caused bruising of tomato was $0.75 \mathrm{~m}$. 
3.3. Application of tomato harvester designtheory

3.3.1.Some parameters required for harvest machine design have been investigated as follows

- The cutting bar width should be more than the spacing between the rows of plants.
- Conveyor belt is plant matter and shaker for fruit cleaning.

- Clearance is between rigid fingers must be smaller than $46.24 \mathrm{~mm}$ fruit diameter and covered with plastic tube for minimizing the friction.

-The cylinders tangential angle must be more

Table (3) : Main dimensions and some properties of the tomato three cultivars : Florada, Super Strain B and Castle Royal.

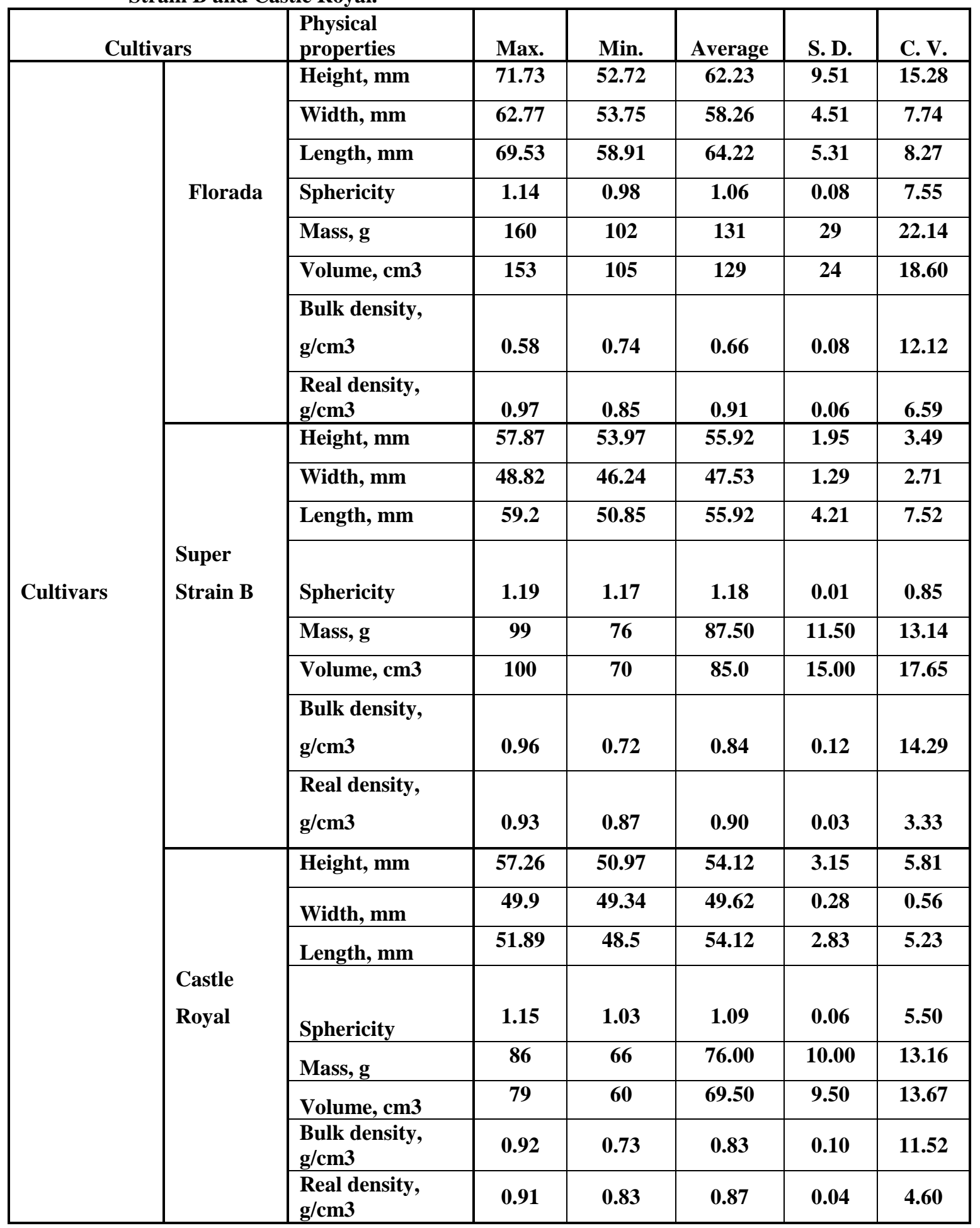


Table (4) : Main dimensions and some properties of the tomato three hybrids: Bregenith, Fanfare and Heinz .

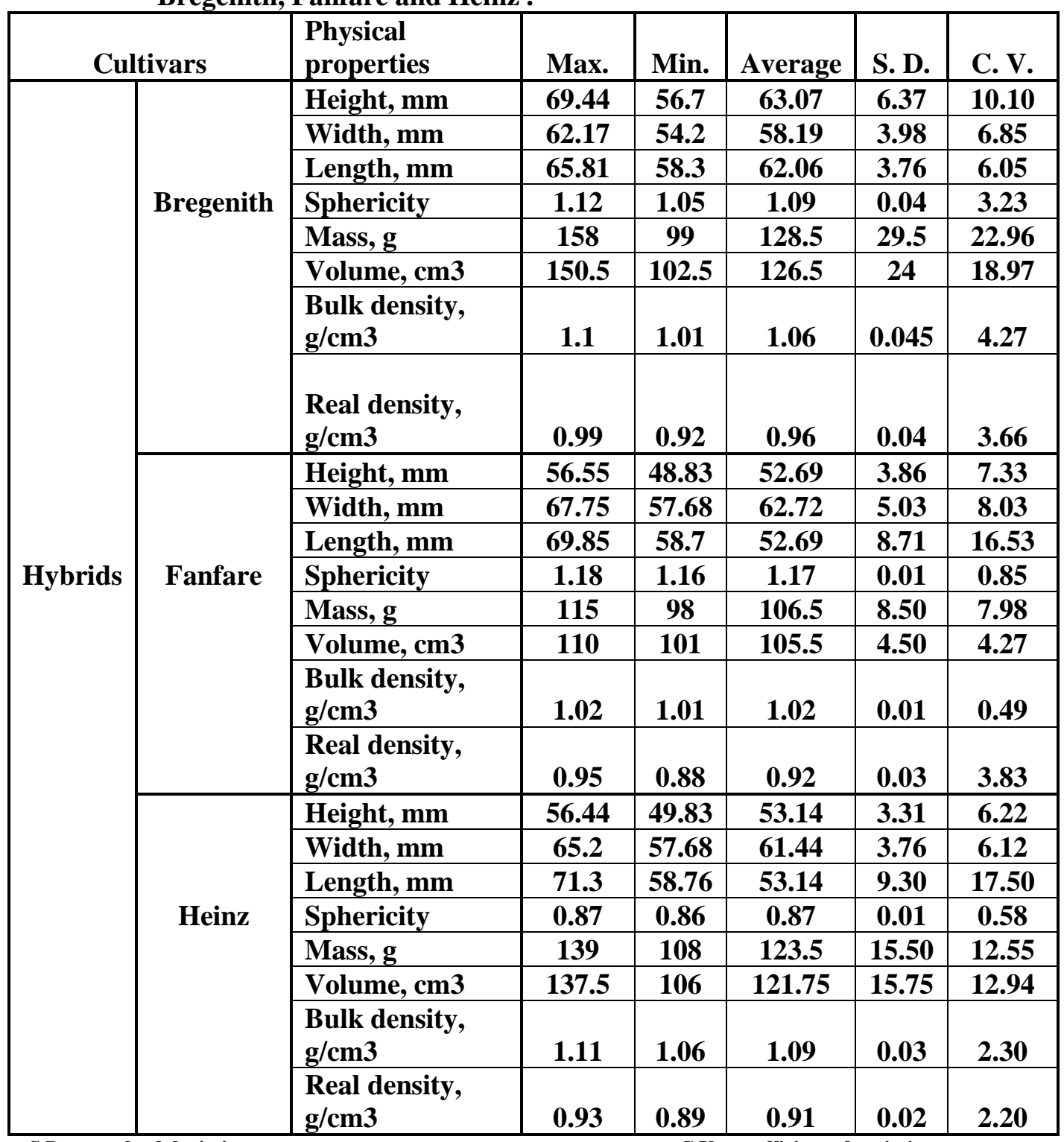

Table (5): Friction and rolling angles for tomato fruits with different surface types.

\begin{tabular}{|l|c|c|c|c|c|c|c|c|c|}
\hline \multirow{3}{*}{$\begin{array}{c}\text { Surface } \\
\text { type }\end{array}$} & \multicolumn{3}{|c|}{ Friction angle, degree } & \multicolumn{6}{|c|}{ Rolling angle, degree } \\
\cline { 2 - 10 } & Max. & Min. & Av. & Max. & Min. & Av. & Max. & Min. & Av. \\
\cline { 2 - 10 } & 19 & 11 & 15 & 40 & 28 & 35 & 28 & 17 & 25 \\
\hline Wood & 17 & 10 & 13.5 & 26 & 22 & 25 & 20 & 13 & 17 \\
\hline Glass & 15 & $\mathbf{8}$ & 11.5 & 25 & 23 & 24 & 19 & 12 & 16 \\
\hline Galv. I. & 15 & 7 & 11.5 & 25 & 21 & 23 & 19 & 12 & 16 \\
\hline Alum. & 15 & 7 & 11 & 25 & 22 & 24 & 20 & 12 & 17 \\
\hline SS. & 15 &
\end{tabular}




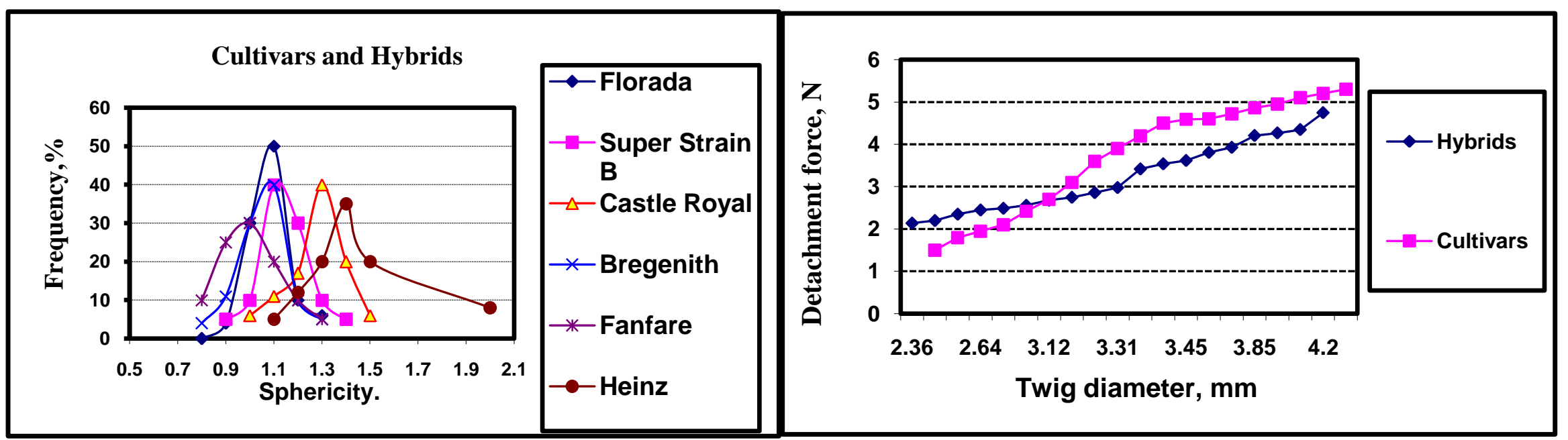

Fig. ( 7 ): Frequency distribution of fruit sphericity of tomato fruits.

Fig. (8): The relationship between twig diameter and detachment force for cultivars and hybrids
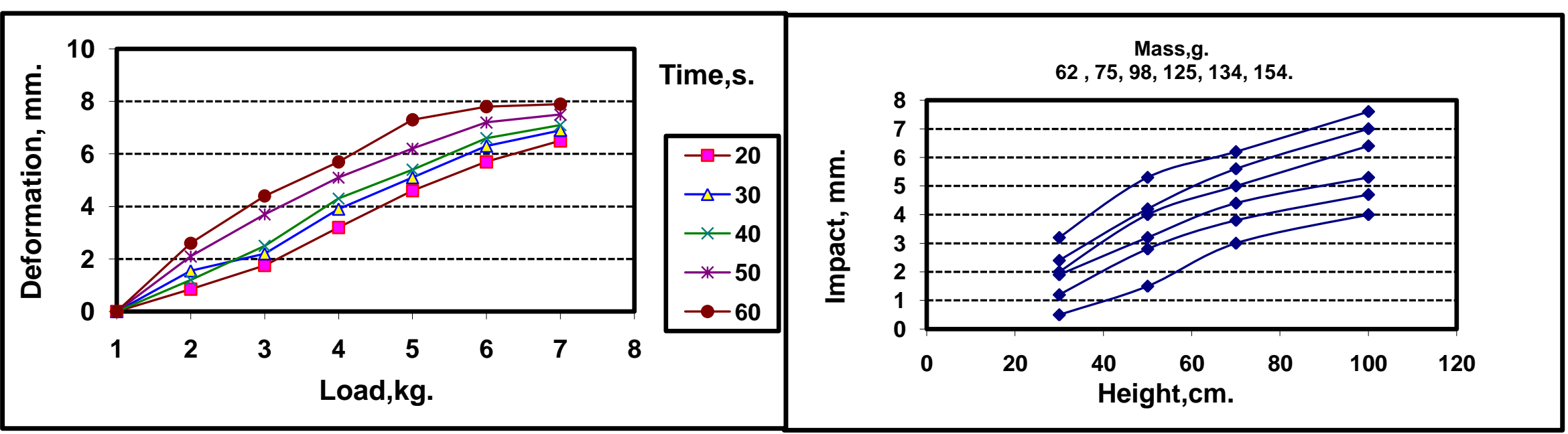

Fig. (9): The maximum impact heights, which cased damage for tomato fruit
Fig. (10): The maximum impact heights, which cased damage for tomato fruit 
than $25^{\circ}$ rolling angles.

- The clearance between the two cylinders must be smaller than $46.24 \mathrm{~mm}$ fruit diameter for the six tomato cultivars and hybrids.

- Feeding rate specified relating to the plants density and machine forward speed.

- The grading machine is conveyed directly behind the harvester for grading fruit into shallow boxes to reduce pressure bruising on the trailer

\subsubsection{Grading drums}

- Three drums used to grade tomato fruit .

- Rotating drums holes used to grade 4 size fruit. Drum hole diameters are 30, 40 and $50 \mathrm{~mm}$, while the largest fruit plants are discharged at the rear of the machine.

- Drums tangential angle more than maximum $25^{\circ}$ rolling angle between tomato fruits and stainless steal surface.

- Machine out put should be more than maximum $17^{\circ}$ friction angle between tomato fruits and stainless steal surface to minimize friction.

\subsubsection{Grading fruit into boxes}

- Space between grading fruits and boxes should be smaller than minimum $75 \mathrm{~cm}$ impact heights to minimize mechanical damage.

- Fruit boxes : The obtained results relieved that the fruit boxes depth should be smaller than 40 $\mathrm{cm}$, to minimize the fruit mechanical damage.

\section{Conclusion}

The main results in this study can be summarized as follows:

Physical properties of tomato fruits for cultivars: Height $=71.73,57.87$, 57.26- 52.72, 53.97, 50.97 mm, Width $=62.77,48.82,49.9-53.75,49.9$, $49.34 \mathrm{~mm}$, Length $=69.53,59.2,51.89-58.91$, $50.85,48.5 \mathrm{~mm}$, Mass $=160,99,86-102,76,66$ $\mathrm{g}$, volume $=153,100,79-105,70,60 \mathrm{~cm}^{3}$,

Physical properties of tomato fruits for hybrids were: Height $=69.44,56.55,56.44-56.7,48.83$, $49.83 \mathrm{~mm}$, Width $=62.17,67.75,65.2-54.2$, $57.68,57.68 \mathrm{~mm}$, Length $=69.81,69.85,71.3-$ 65.3, 58.7, $61.76 \mathrm{~mm}$, Mass $=160-102 \mathrm{~g}$, volume $=150.5,110,137.5-102.5,101,106 \mathrm{~cm}^{3}$. Mechanical properties of tomato: The deformation range increased from I0.85- 2.6 to $6.5-7.9$ by increasing loading from 1 to 6 N., and increasing time from 20 to 60 s.

Using physical and mechanical properties of tomato in the design of the harvest machine for different cultivars and hybrids of tomato are summarized as follows :

Harvest unit : The cutting bar width should be more than the spacing between the rows of plants. Conveyor belt is plant matter and shaker for fruit cleaning. Clearance between rigid fingers is smaller than $46.24 \mathrm{~mm}$ with plastic tube covered. Fruit-laden plants are carried up the $45^{\circ}$ incline to a height of about $160 \mathrm{~cm}$ from bed surface. Two cylinders are tending with angle of $25^{\circ}$, with 46.24 $\mathrm{mm}$ clearance between them. Feeding rate specified relating to the plants density and machine forward speed.

Grading drums : Rotating drums used be 3 hole size diameters 50,55 and $60 \mathrm{~mm}$, while the largest fruit plants are discharged at the rear of the machine. Drums tangential angle should be more than $25^{\circ}$. Machine out put should be more than $17^{\circ}$. Space between grading fruit and boxes should be smaller than $75 \mathrm{~cm}$.

\section{REFERENCES}

Abd-Allah E. M. (1995). Genetic studies in tomato. Ph. D. Thesis, Fac. Agric., Minia. Univ.,

Balls R. C. (1986). Horticultural engineering technology fixed equipment and buildings. MacMillan Publishers, 18-31.

Bishop C.F.H. and Maunder W.F. (1990). Potato mechanization and storage. Farming Press Limited Wharfedal Rood, Ipswich, Suffolk 156-161.

Buyanov A. I. and Voronyuk B. A. (1985). Physical and mechanical properties of plants, fertilizers and soils. Amerind Pub. Co. PVT. LTD. New Delhi, Bombay, Calcutta, New York: 15-57.

El-Raie A.E.S., Hendawy N.A. and Taib A.Z., (1996). Study of physical and engineering properties for some agricultural products. Misr J. Agric. Eng. 13(1): 211-226.

Ghonim Y. E. (1986). Properties of some citrus fruit related to mechanical harvesting. Misr J. Ag.Eng. 3(3): 3-17.

Hanna F. K., Ismail Z.E. and Abdel-Hakim G.R. (1993). Factors affecting grain cleaning efficiency. Part 1: Grain straw mixture and characteristics, Misr J. Ag.Eng. 10(2): 369382.

Haydar H., Ibrahim G., Mehmet O. and Bayram M. (2007). Post harvest chemical and physical-mechanical properties of some apricot varieties cultivated in Turkey. Journal of Food Engineering 79 : 364-373.

Hojat A., Hamzeh F. and Hossein M. (2008). Some physical and mechanical properties of apricot fruits, pits and kernels (C.V Tabarzeh) American-Eurasian J. Agric. and Environ. Sci., 3 (5): 703-707.

Huang Y., Shyushyang L. and Chang Y. C. 
(2000). The study on the physical property indices of grading for Indian Jujube. $\mathbf{J}$ Agric. and Foresty. 49(4), 47-62.

Mouhamed M. A. H. and Hewedy A. R. (1994). Assessment of response of some tomato determinate cultivars to high temperature. Egypt. J. Hort. 21 No. 2, PP. 161-185.
Mohsenin N. N. (1986). Physical properties of planting and animal materials. Gordon and Breach Soc. Pub. N. Y. PP. 20:35, 734.

Peterson D. L. and Colario G. (1990). Assessing damage susceptibility of peach cultivars for mechanical harvesting. ASAE Paper No. 90-6004. ASAE, St. Joseph, MI.

\section{الخصائص الطبيعية والميكانيكية لنباتات وثمار الطماطم وإستخدامها فى تصميم آلة حصاد ميرفت محمد عطاللة}

معهذ بحوث الهندسة الزر اعية - مركز البحوث الزر اعية- الجيزة - مصر.

\section{ملخص}

تعد الطماطم من أهم محاصيل الخضر وتأتى فى المرتبة الأولى من حيث المساحة المنزر عة سنويا والانتئاج و الاستهلاك.

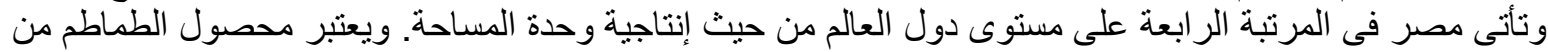

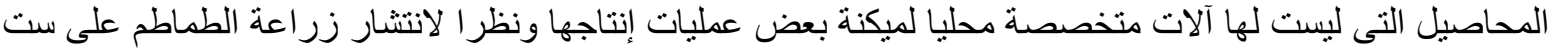

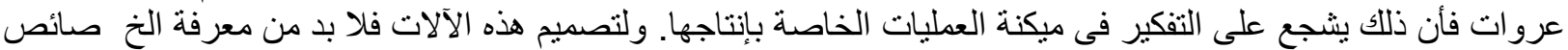

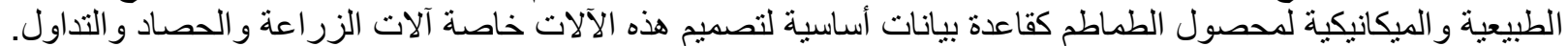

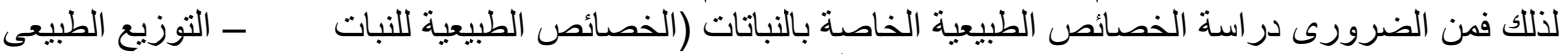

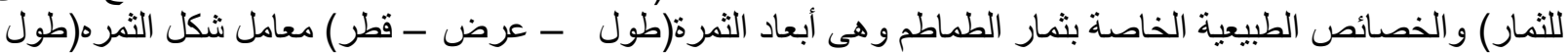

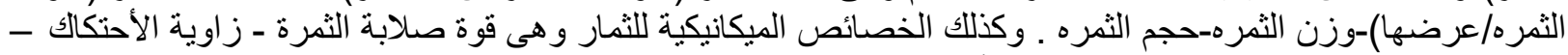

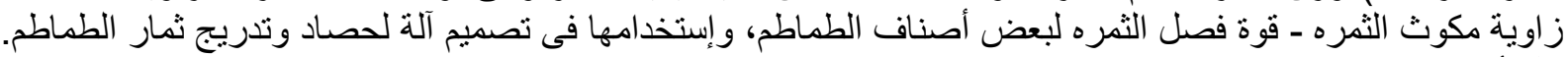
وقد أوضحت النتائج ما يلى الفيره الخصائص الطبيعية

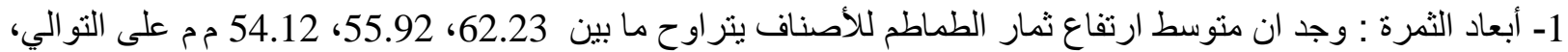

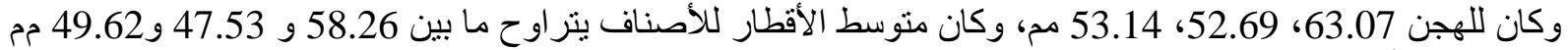

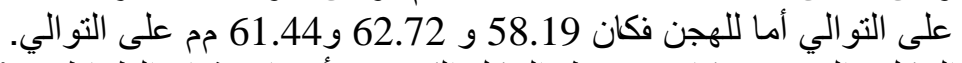

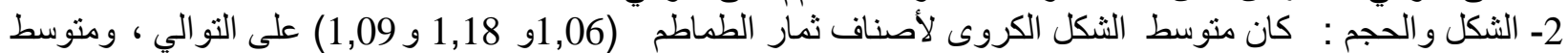

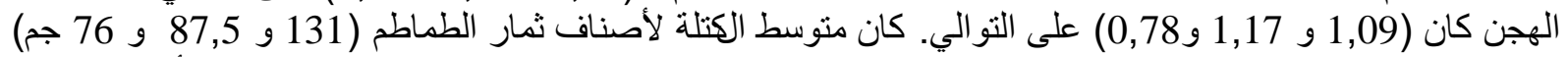

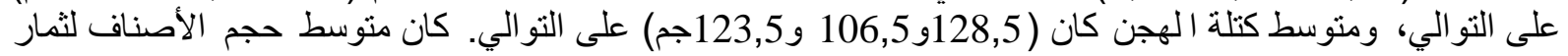

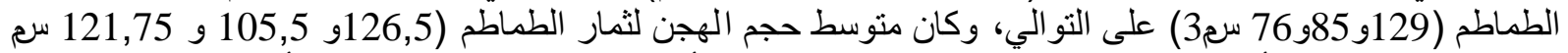
3) على النو الي ووجد أن 85.8 \% من الثمار الموجودة فى العينة تأخذ الثكل الكروى، 14.2 \% تأخذ الثكل المفلطح. الخصائص الميكانيكية عالتية

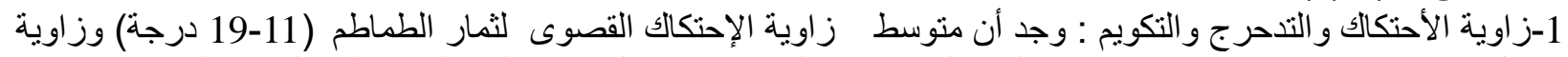

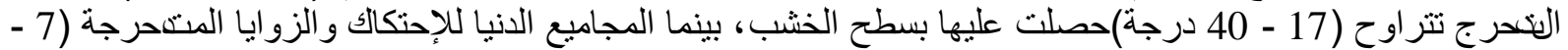

$$
15 \text { و12 - } 19 \text { على التو الي) حصلا عليه بسطح الألومنيوم. }
$$

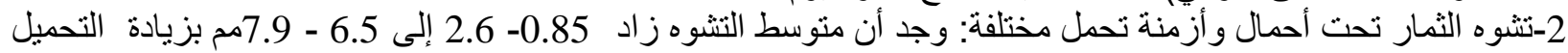

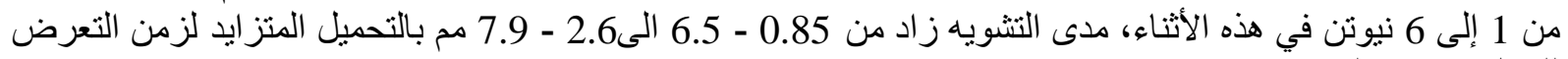

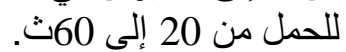
3-اعلى ارتفلعات التأثير القصوى، التي تسبيت فى الضرر كان 1.0 م. بينما إرتفاع التنأثير الذي سبب فى حدوث الكدمة كانت 0.75م.

* توصيف لبعض الخصائص الطبيعية و الميكانيكية لتصميم الة الحصاد ووحدة التدريج لمحصول الطماطم. 